Ilaria Gandoglia, MD

Federico Ivaldi

Alice Laroni, MD, $\mathrm{PhD}$

Federica Benvenuto, $\mathrm{PhD}$

Claudio Solaro, MD

Gianluigi Mancardi, MD

Nicole Kerlero de Rosbo,

$\mathrm{PhD*}$

Antonio Uccelli, MD*

Correspondence to

Dr. Uccelli:

auccelli@neurologia.unige.it

\section{Teriflunomide treatment reduces B cells in patients with MS OPEN}

\section{ABSTRACT}

Objective: To study the immunomodulatory effect of teriflunomide on innate and adaptive immune cell populations through a pilot, open-label, observational study in a cohort of patients with relapsing-remitting MS.

Methods: Blood lymphocytes were isolated from 10 patients with MS before and after 3 or 12 months of treatment. Adaptive and innate immune cell subsets were analyzed by flow cytometry as follows: B cells (memory, regulatory, and mature subsets), T cells (effector and regulatory subsets), and natural killer (NK) cells (CD56 dim and CD56 bright subsets).

Results: Our results show that teriflunomide significantly reduces absolute counts of total CD19+ B cells and mature and regulatory B-cell subsets. T cells were affected to a lesser extent, with a trend in reduction of absolute counts for both T effector CD4+ cells (Th1, Th17 and Th1/ 17) and T regulatory $\mathrm{CD} 8^{+}$and $\mathrm{CD} 4^{+}$cells. Teriflunomide had no detectable effect on NK-cell numbers.

Conclusions: In our small cohort, teriflunomide treatment affects mainly and significantly on B-cell numbers, while having a milder effect on T-cell numbers. Larger cohorts are necessary to confirm these findings and understand the effect of teriflunomide on the functionality of these cells. Neurol Neuroimmunol Neuroinflamm 2017;4:e403; doi: 10.1212/NXI.0000000000000403

\section{GLOSSARY}

EDSS $=$ Expanded Disability Status Scale; IFN $\gamma=$ interferon gamma; NK = natural killer; RR-MS = relapsing-remitting MS; Teff $=$ effector $T$ cell; Treg $=$ regulatory $T$ cell.

The main mechanism of action of teriflunomide, a drug approved for treatment of relapsingremitting MS (RR-MS), relies on the inhibition of dihydroorotate dehydrogenase, which catalyzes de novo biosynthesis of pyrimidines. Cells with high proliferative rates, such as activated lymphocytes, are therefore affected by teriflunomide. ${ }^{1}$ Accordingly, treatment with teriflunomide decreases proliferation of $\mathrm{T}$ and $\mathrm{B}$ lymphocytes. ${ }^{2}$ Clinical trials (teriflunomide multiple sclerosis oral and teriflunomide oral in people with relapsing multiple sclerosis) ${ }^{3}$ have shown that teriflunomide treatment is associated with an early $15 \%$ mean decrease in leukocyte counts. However, the effect of teriflunomide on different immune cell subpopulations has not been properly addressed so far. Therefore, we have investigated how teriflunomide treatment affects immune cell populations in MS.

METHODS Flow cytometry analysis. Mononuclear cells were isolated from the peripheral blood by Ficoll gradient centrifugation (Lympholyte-H, Cedarlane), and flow cytometry analysis, using the BD LSRFortessa flow cytometer and FACSDiva 7 Software, was performed in 4 tubes using the following conjugated antibodies (Becton Dickinson, Franklin Lakes, NJ): anti-CD3 (V500), anti-CD4 (allophycocyanin [APC]-H7), anti-CD8 (PercCP-Cy5.5), anti-CD28 (phycoerythrin [PE], anti-CD25 (PE.Cy7), anti-CD127

*These authors contributed equally as last authors to this work.

From the Department of Neurosciences, Rehabilitation, Ophthalmology, Genetics, Maternal and Child Health Unit (I.G., A.L., F.B., G.M., N.K. d.R., A.U.), and Center of Excellence for Biomedical Research (CEBR) (F.I., A.L., G.M., A.U.), University of Genoa, Italy; Ospedale Policlinico San Martino-IRCCS (A.L., G.M., A.U.), Genoa, Italy; and Rehabilitation Unit (C.S.), Centro di Recupero e Rieducazione Funzionale, M.L. Novarese, Moncrivello, Italy.

Funding information and disclosures are provided at the end of the article. Go to Neurology.org/nn for full disclosure forms. The Article Processing Charge was funded by the authors.

This is an open access article distributed under the terms of the Creative Commons Attribution-NonCommercial-NoDerivatives License 4.0 (CC BY-NC-ND), which permits downloading and sharing the work provided it is properly cited. The work cannot be changed in any way or used commercially without permission from the journal. 
(BV421), anti-CD45RA (APC), anti-CCR6 (APC), anti-CD161 (B421), anti-CCR4 (PE.Cy7), and anti-CXCR3 (PE) for effector (Teff) and regulatory $\mathrm{T}$ (Treg) cells; anti-CD19 (PE.Cy7), antiCD38 (APC), and anti-CD24 (PE) for B cells; and anti-CD3 (V500), anti-CD16 (PerCp-Cy5.5), and anti-CD56 (BV421) for natural killer (NK) cells.

Flow-Count Fluorospheres (Beckman Coulter, Galway, Ireland) were used to obtain absolute cell counts.

MS patient cohort. The longitudinal, open-label, observational study was performed on a cohort of 10 patients with RR-MS; of these, 3 were analyzed before treatment (T0) and after 3 months (T3), and 7 at T0 and after 12 months (T12) of treatment. The 3 patients followed for 3 months ( 2 men and 1 woman) had a mean age of $43.6 \pm 1.5$ years, a mean Expanded Disability Status Scale (EDSS) score of $3.0 \pm 1.5$ throughout treatment, and a mean disease duration of $15.3 \pm 10.5$ years. One patient had been treated with mitoxantrone for 6 years previously. The 7 patients followed for 12 months were all women with a mean age of $54.8 \pm$ 8.9 years; the mean EDSS score was $3.0 \pm 1.5$ and $3.1 \pm 1.7$ before and after 12 months of treatment, respectively, and a mean disease duration of $13.4 \pm 4.8$ years. One patient had been treated with cyclophosphamide and mitoxantrone 7 years previously. Other previous treatments included interferon $\beta-1 \mathrm{a}$, interferon $\beta-1 \mathrm{~b}$, natalizumab, and dimethyl fumarate. Patients did not experience relapses during treatment.

Patients were enrolled according to the following criteria: age 18 years and older, with a diagnosis of RR-MS (Poser or McDonald criteria) and an EDSS score of 0-6.5, and able to provide written informed consent.

Ethics approval. This study was approved by the Ethics Committee of Ospedale Policlinico San Martino-IRCCS, Genoa, Italy, No. 190/12.

Figure 1 B cells decrease significantly in patients with MS during teriflunomide treatment

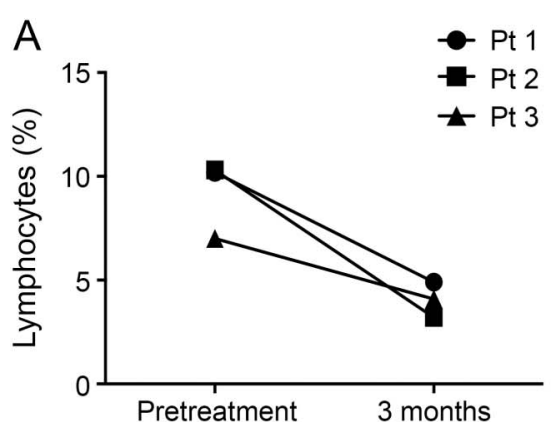

B
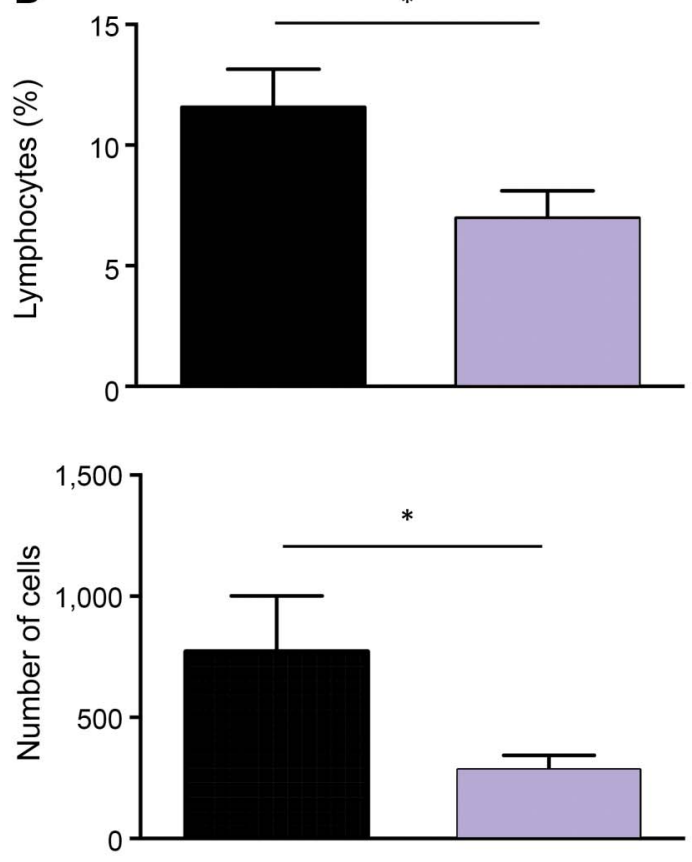
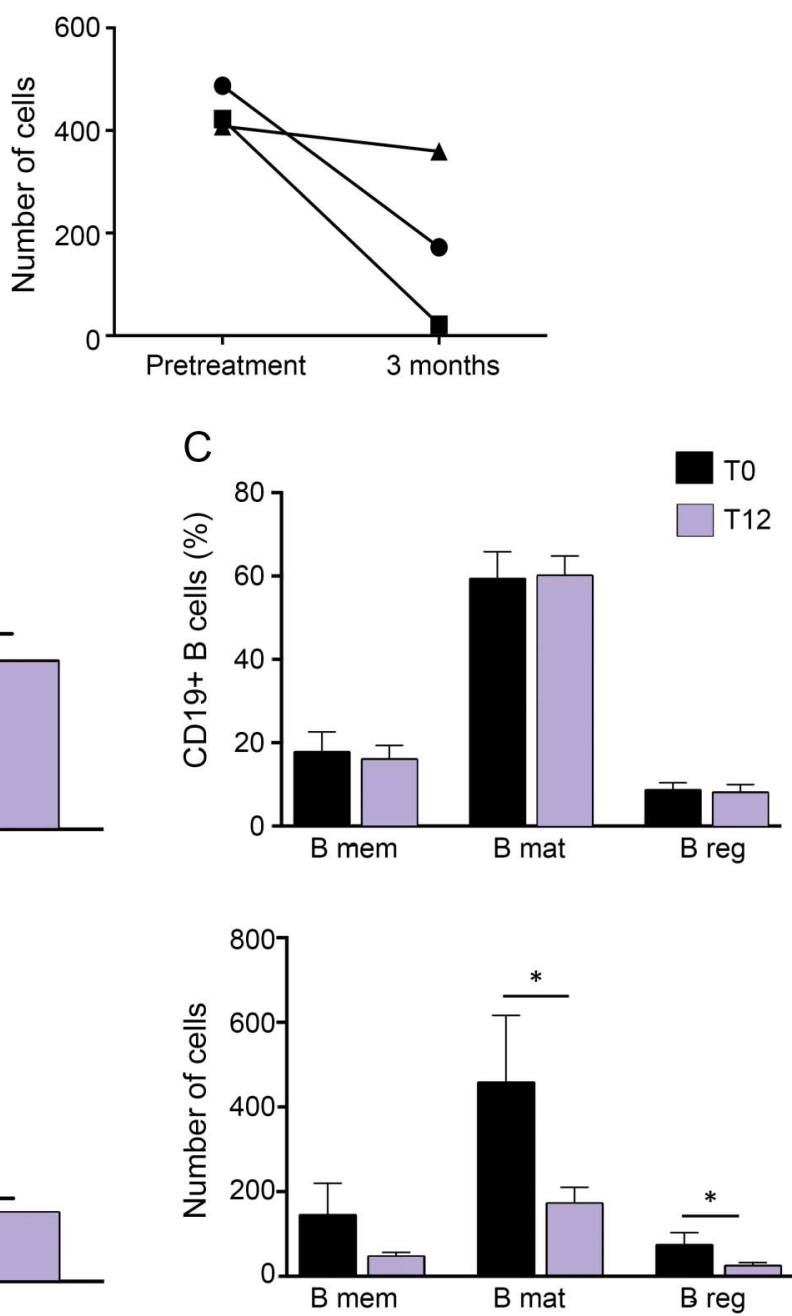

$B$ cells are assessed as $\mathrm{CD} 3^{-} \mathrm{CD} 14^{-} \mathrm{CD} 19^{+}$of which subpopulations are identified as $\mathrm{B}$ memory $\left(\mathrm{B}\right.$ mem $\left.\mathrm{CD} 24^{+} \mathrm{CD} 38^{-}\right), \mathrm{B}$ mature ( $\mathrm{B}$ mat $\left.\mathrm{CD} 24{ }^{+} \mathrm{CD} 38^{\text {low }}\right)$, and $\mathrm{B}$ regulatory ( $\mathrm{B}$ reg $\left.\mathrm{CD} 24{ }^{+} \mathrm{CD} 38^{\text {high }}\right)$. (A) $\mathrm{A}$ clear trend in reduction of $\mathrm{B}$-cell number and percentage was observed in 3 patients treated for 3 months. (B) B-cell percentage (upper panel) and numbers (lower panel) were reduced after 1 year of treatment with teriflunomide. Data are presented as mean \pm SEM for 7 treated patients with MS. * $p<0.05$. (C) While the proportions of the different B-cell subpopulations did not change after 12 months of treatment (upper panel), numbers of $B$ mat and $B$ reg cells were decreased $(* p<0.05$ ), and B mem cell numbers showed a clear trend to decrease (lower panel). Data are presented as mean \pm SEM for 7 treated patients with MS. 
Statistical analyses. Statistical analyses were performed using Graph-Pad Prism v.6.00 (GraphPad Software, San Diego, CA). Statistical significance was evaluated using the paired Student $t$ test (Wilcoxon matched-pairs signedrank test). $p$ Values $\leq 0.05$ were considered statistically significant.

RESULTS A preliminary assessment by flow cytometry of the effect of teriflunomide on broad immune cell subsets $\left(\mathrm{CD}^{+} \mathrm{T}\right.$ cells, $\mathrm{CD} 19^{+} \mathrm{B}$ cells, and $\mathrm{CD} 56^{+} \mathrm{NK}$ cells) in 3 patients after a three-month treatment indicated that $\mathrm{CD} 19^{+} \mathrm{B}$-cell percentage and numbers decreased in all 3 patients (figure 1A), while no apparent effect was observed in the other cell populations (data not shown). To further define the effect of teriflunomide, we evaluated its effect on cell number and proportion of relevant immune cell subsets after a 12-month treatment in 7 different patients. As expected, the overall lymphocyte counts in all treated patients were slightly decreased (by around 10\%; data not shown).

$B$ cells decrease in patients with MS during teriflunomide treatment. A significant reduction in cell number and percentage of $\mathrm{B}$ cells overall was confirmed in patients treated for 12 months (figure $1 \mathrm{~B}$ ). While the proportions of the different B-cell subpopulations remained stable (figure $1 \mathrm{C}$ upper panel), B mature and $\mathrm{B}$ regulatory cell numbers were significantly decreased, and B memory cells also

Figure 2 T effector and regulatory cell numbers show a slight trend in reduction after 12 months of teriflunomide treatment
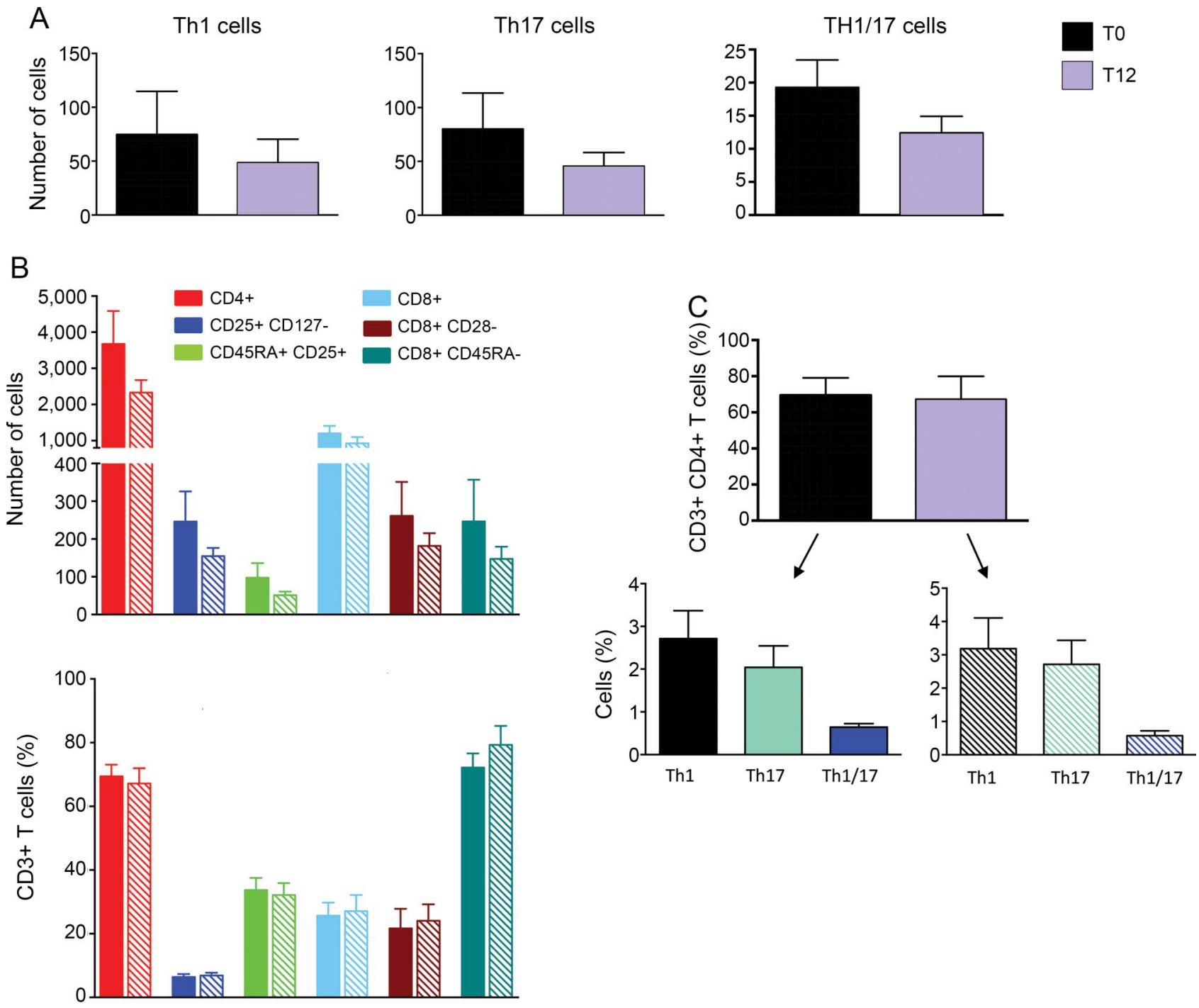

Effector T-cell populations were assessed as Th1 (CD $\left.\left.{ }^{+} \mathrm{CD} 4{ }^{+} \mathrm{CCR} 6{ }^{-\mathrm{CD} 161}\right)^{-}\right)$, Th17 $\left(\mathrm{CD} 3^{+} \mathrm{CD} 4{ }^{+} \mathrm{CCR} 6{ }^{+} \mathrm{CD} 161^{+}\right)$, and Th1/17

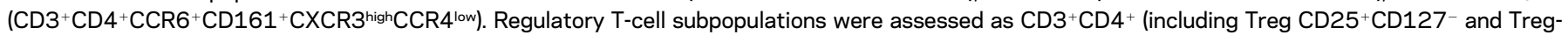
naive $\mathrm{CD} 45 \mathrm{RA}^{+} \mathrm{CD}^{2} 5^{\text {low) }}$ and $\mathrm{CD}^{+}{ }^{+} \mathrm{CD} 8^{+}$(including Treg $\mathrm{CD}^{2} 8^{-}$and Treg-naive $\mathrm{CD} 28^{-} \mathrm{CD} 45 \mathrm{RA}^{+}$). (A) T effector cell numbers show a trend in decrease after 12 months of treatment. (B) The proportion between different regulatory T-cell subsets is not affected by teriflunomide (lower panel). The number of cells is slightly reduced in all subpopulations after 12 months of treatment (upper panel). (C) The proportion between different T effector cell subsets is not affected by the treatment. Data are presented as mean \pm SEM for 7 treated patients with MS. 

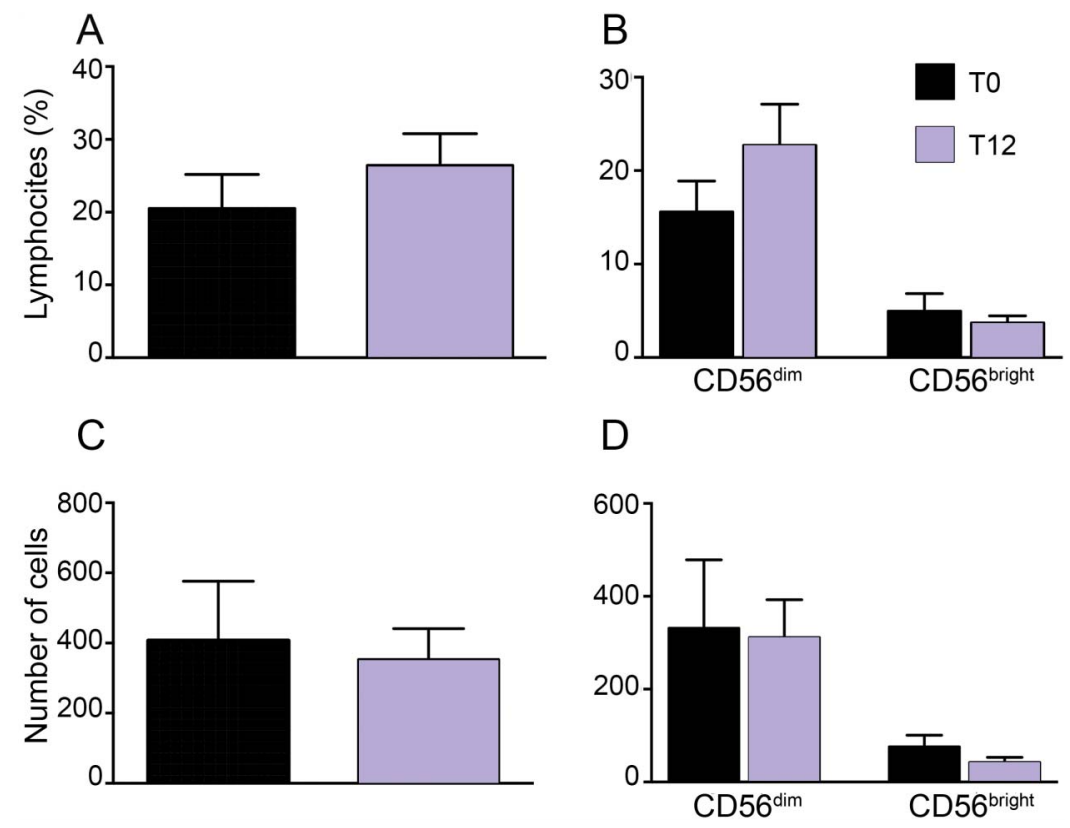

NK cells are assessed as $\mathrm{CD} 3^{-} \mathrm{CD} 14^{-} \mathrm{CD} 56^{\text {bright }}$ and $\mathrm{CD} 3^{-} \mathrm{CD} 14^{-} \mathrm{CD} 56^{\mathrm{dim}}$ cells. The percentage of the overall population (A) or the CD56 bright and CD56 dim subsets (B) did not change on treatment, nor did the actual cell number (C and D, respectively). Data are presented as mean \pm SEM for 7 treated patients with MS.

decreased, albeit not significantly (figure $1 \mathrm{C}$ lower panel).

Teriflunomide treatment slightly decreases $\mathrm{T}$-cell numbers, albeit nonsignificantly. A slight trend to reduced numbers was seen in Teff (figure 2A) and Treg (figure 2B upper panel) cells after 12 months of treatment, whereas the percentage of Teff and Treg cells did not change (figure $2 \mathrm{C}$ and figure $2 \mathrm{~B}$, lower panel).

Teriflunomide treatment does not decrease NK-cell numbers. Figure 3 shows that percentage and numbers of total NK cells remained stable after 12 months of treatment (figure 3, A and C), and there was no difference in the proportion and absolute counts of CD56 bright and CD56 dim $\mathrm{NK}$ cells (Figure 3, B and D).

DISCUSSION MS is an inflammatory autoimmune disease involving several types of immune cells with effector and regulatory functions including $\mathrm{T}$ and $\mathrm{B}$ lymphocytes. While autoreactive $\mathrm{CD}^{+}$Teff cells are believed to drive autoimmune diseases when they escape central tolerance, several mechanisms have evolved to regulate their function in the periphery and prevent autoimmunity. Different Treg-cell subsets have been characterized as being able to suppress lymphocyte effector functions either directly or by acting on antigen-presenting cells, therefore preventing the development of autoimmunity. In MS, Treg suppression has been reported to be dysfunctional. The role of Th1 interferon gamma (IFN $\gamma$ )- secreting cells is well known as a major protagonist in demyelinating damage in $\mathrm{MS}^{4}$; more recently, other Teff-cell subpopulations have been discovered to have a major role in the inflammatory process of MS: Th17 and Th1/17 lymphocytes secreting IFN $\gamma$ and/ or interleukin-17. In particular, Th1/17 cells are increased in patients with MS compared with healthy donors during active phases of disease. ${ }^{5}$ Our data show that the numbers of circulating Teff and Treg cells are slightly, albeit not significantly, decreased by teriflunomide treatment. As teriflunomide affects predominantly cells that are highly proliferative, this suggests that, in our cohort of patients who did not suffer any relapse during the period of observation, the rate of proliferation of these cells is likely low.

$\mathrm{B}$ lymphocytes are emerging as key player in the pathogenesis of MS. Three B-cell subsets have been described: effector, regulatory, and memory cells characterized by different roles depending on the production of antibody and of different cytokine types. Aberrant profiles of both types of cytokine responses have been observed in $\mathrm{B}$ cells from patients with MS. ${ }^{6}$ Our study shows that teriflunomide significantly decreases cell numbers of effector B-cell subsets, confirming the importance of targeting $\mathrm{B}$ cells to obtain clinical and radiologic stabilization of disease, as shown with B-cell-specific treatments such as rituximab ${ }^{7}$ and ocrelizumab. ${ }^{8}$ The effect of teriflunomide on mature $\mathrm{B}$ cells may be of clinical importance in view of the observed recirculation of B cells between peripheral tissues and the CNS, ${ }^{9}$ 
with a possible pathogenetic effect. However, teriflunomide also decreases the Breg-cell subset, as its effect on lymphocytes is not specific toward a single cell population, but rather targets proliferating cells. It is as yet unknown what are the roles of Breg cells in MS and the clinical relevance of changes induced by treatments on this cell population. However, it should be noted that efficient specific B-cell-depleting treatments such as rituximab and ocrelizumab, would also affect the Breg-cell population. In this context, beyond its current utilization as first-line therapy in MS subjects, teriflunomide could be also considered as maintenance treatment after induction therapy.

Our data show that teriflunomide treatment influences immune cell subsets involved in the pathogenesis of MS, more specifically B cells and, to a lower extent, $\mathrm{T}$ cells. However, further studies with larger cohorts and targeting cell functionality are necessary to clarify the basis of its efficacy in MS.

\section{AUTHOR CONTRIBUTIONS}

Ilaria Gandoglia: acquisition of data, analysis, and interpretation. Federico Ivaldi: acquisition of data. Alice Laroni: study concept and design and critical revision of the manuscript for important intellectual content. Federica Benvenuto: acquisition of data. Claudio Solaro: critical revision of the manuscript for important intellectual content. Gianluigi Mancardi: study supervision. Nicole Kerlero de Rosbo: study concept and design, critical revision of the manuscript for important intellectual content, and study supervision. Antonio Uccelli: critical revision of the manuscript for important intellectual content, study supervision.

\section{ACKNOWLEDGMENT}

The authors thank the nursing staff of the Neurological Clinic of Genoa for their help with patients, and the patients themselves for their cooperation.

\section{STUDY FUNDING}

No targeted funding reported.

\section{DISCLOSURE}

I. Gandoglia has received funding for travel from Biogen, Novartis, and Genzyme and honoraria from Amirall. F. Ivaldi reports no disclosures. A. Laroni has received consulting honoraria and/or speaker fees from Novartis, Genzyme, Biogen, Sanofi, Merck Serono, and Teva and received research support from Biogen. F. Benvenuto reports no disclosures. C. Solaro has served on the advisory boards for Biogen, TEVA, Novartis
Genzyme, Merck Serono, and GW Pharma; received speaking honoraria from Biogen, Merck Serono, Almirall, Teva, Novartis, GW Pharma, and Genzyme; and received research support from the Italian Multiple Sclerosis Foundation. G. Mancardi has received honoraria and financial support for travel expenses and research from Biogen, Genzyme, Teva, Merck Serono, Bayer Schering, Sanofi-Aventis, and Novartis and received research support from the Italian Multiple Sclerosis Society. N. Kerlero de Rosbo reports no disclosures. A. Uccelli has received consulting honoraria and/or speaker fees from Genentech, Athersys, Sanofi-Aventis, Tohoku University Graduate School of Medicine, Roche, Biogen, Genzyme, Teva, Novartis, and Merck Serono; served on the scientific advisory board for Genentech, Roche, and Allergan; and received research support from Bayer Schering, Sanofi-Aventis, the Italian Ministry of Health, Regione Liguira Progetto LIMONTE, Ricera Sanitaria Regionale, and Fondazione CARIGE. Go to Neurology.org/nn for full disclosure forms.

Received April 26, 2017. Accepted in final form August 10, 2017.

\section{REFERENCES}

1. Bar-Or A. Teriflunomide (Aubagio(R)) for the treatment of multiple sclerosis. Exp Neurol 2014;262:57-65.

2. Li L, Liu J, Delohery T, Zhang D, Arendt C, Jones C. The effects of teriflunomide on lymphocyte subpopulations in human peripheral blood mononuclear cells in vitro. J Neuroimmunol 2013;265:82-90.

3. Confavreux C, O'Connor P, Comi G, et al. Oral teriflunomide for patients with relapsing multiple sclerosis (TOWER): a randomised, double-blind, placebo-controlled, phase 3 trial. Lancet Neurol 2014;13:247-256.

4. Kleinewietfeld M, Hafler DA. Regulatory $\mathrm{T}$ cells in autoimmune neuroinflammation. Immunol Rev 2014;259: 231-244.

5. Jones AP, Kermode AG, Lucas RM, Carroll WM, Nolan D, Hart PH. Circulating immune cells in multiple sclerosis. Clin Exp Immunol 2017;187:193-203.

6. Duddy M, Niino M, Adatia F, et al. Distinct effector cytokine profiles of memory and naive human $\mathrm{B}$ cell subsets and implication in multiple sclerosis. J Immunol 2007;178: 6092-6099.

7. Hauser SL, Waubant E, Arnold DL, et al. B-cell depletion with rituximab in relapsing-remitting multiple sclerosis. $\mathrm{N}$ Engl J Med 2008;358:676-688.

8. Hauser SL, Bar-Or A, Comi G, et al. Ocrelizumab versus interferon beta-1a in relapsing multiple sclerosis. N Engl J Med 2017;376:221-234.

9. Stern JN, Yaari G, Vander Heiden JA, et al. B cells populating the multiple sclerosis brain mature in the draining cervical lymph nodes. Sci Transl Med 2014;6:248ra107. 


\section{Neurology \\ Neuroimmunology \& Neuroinflammation}

Teriflunomide treatment reduces $B$ cells in patients with MS

Ilaria Gandoglia, Federico Ivaldi, Alice Laroni, et al.

Neurol Neuroimmunol Neuroinflamm 2017;4;

DOI 10.1212/NXI.0000000000000403

This information is current as of October 23, 2017

\section{Updated Information \& Services}

References

Citations

Subspecialty Collections

Permissions \& Licensing

Reprints including high resolution figures, can be found at: http://nn.neurology.org/content/4/6/e403.full.html

This article cites 9 articles, 2 of which you can access for free at: http://nn.neurology.org/content/4/6/e403.full.html\#\#ref-list-1

This article has been cited by 2 HighWire-hosted articles: http://nn.neurology.org/content/4/6/e403.full.html\#\#otherarticles

This article, along with others on similar topics, appears in the following collection(s):

All Clinical Neurology

http://nn.neurology.org//cgi/collection/all_clinical_neurology All Immunology

http://nn.neurology.org//cgi/collection/all_immunology Multiple sclerosis

http://nn.neurology.org//cgi/collection/multiple_sclerosis

Information about reproducing this article in parts (figures,tables) or in its entirety can be found online at:

http://nn.neurology.org/misc/about.xhtml\#permissions

Information about ordering reprints can be found online: http://nn.neurology.org/misc/addir.xhtml\#reprintsus

Neurol Neuroimmunol Neuroinflamm is an official journal of the American Academy of Neurology.

Published since April 2014, it is an open-access, online-only, continuous publication journal. Copyright

Copyright (C) 2017 The Author(s). Published by Wolters Kluwer Health, Inc. on behalf of the American

Academy of Neurology.. All rights reserved. Online ISSN: 2332-7812.

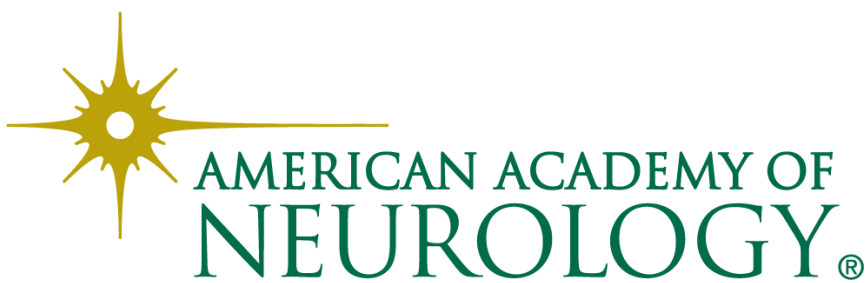

